\title{
GROWTH EFFECTS OF REMITTANCES: NEW EVIDENCE FROM PAKISTAN
}

\author{
Luigi Pio Leonardo Cavaliere \\ Department of Economics, University of Foggia, Via Romolo Caggese, Foggia FG, Italy \\ Sanam Wagma Khattak* \\ Lecturer, Department of Economics, University of Peshawar, Pakistan.

\section{Ester Salvato} \\ Department of Economics, University of Foggia, Foggia, Italy \\ *Corresponding Author
}

\begin{abstract}
Remittances are an essential component of human life in the age of globalization, and the primary aim of this study is to examine the effect of international remittances on economic growth in a developing and an emerging economy like Pakistan. The time series data from 1976 to 2019 used in this study and apply different time series estimation techniques. The remittance data comes from State Bank of Pakistan and in US\$ million while Economic Growth or GDP data comes from world development indicators, World Bank and in current US\$. The results confirms that both short-run and long-run association exist between remittances and economic growth in Pakistan. Thus, results show that, the remittance flows to Pakistan have a positive impact on Individual Pakistani as well as on macroeconomic scenario of Pakistan. The results parameters stability tests, CUSUM and CUSUMQ confirms the stability of parameters. Government should adopt such policies that encourage overseas Pakistanis to send remittances through official channel.
\end{abstract}

Key words: Remittances, Economic Growth, Time Series, Pakistan.

Cite this Article: Luigi Pio Leonardo Cavaliere, Sanam Wagma Khattak and Ester Salvato, Growth Effects of Remittances: New Evidence from Pakistan, International Journal of Management, 11(12), 2020, pp. 2592-2601.

http://iaeme.com/Home/issue/IJM?Volume $=11 \&$ Issue $=12$

\section{INTRODUCTION}

Remittances are the wages of refugees sent back to their families, which are the lifeline for many people living in the underdeveloped and developing countries around the world. This money is heavily relied on by many individuals. The remittances cover a large or part of their 
financial responsibility. This foreign currency is used by left-behind family members for their economic or monetary problems like consumption, saving, investment and insurance.

Globally, the flow of remittances have increased from US\$385 to US $\$ 440$ billion between 2007 and 2010 and are estimated to grow at the rates of $7 \%$ to $8 \%$ annually between 2011 and 2013 to hit US\$536 by 2023. Developing nations received 325 billion of these amounts, East Asian Pacific region received 91 billion, EU and Central Asian economies received 37 billion and 58 billion by Latin America Caribbean countries while the Middle East received 91 billion (Dilip Ratha, Sanket Mohapatra and Ani Silwal-2011).

Table 1 Outlook of remittance flows for 2010-23

\begin{tabular}{|l|c|c|c|c|}
\hline \multicolumn{1}{|c|}{ Regions } & \multicolumn{2}{c|}{ 2010e } & \multicolumn{2}{c|}{ 2023f } \\
\hline & Remittances & Growth (\%) & Remittances & Growth (\%) \\
\hline World & 440 & 5.4 & 536 & 7.3 \\
\hline Developing Countries & 325 & 5.6 & 404 & 7.9 \\
\hline East Asia and Pacific & 91 & 7.4 & 117 & 9.5 \\
\hline Europe and Central Asia & 37 & 1.3 & 46 & 8.8 \\
\hline Latin America and Caribbean & 58 & 1.7 & 74 & 8.6 \\
\hline Middle East and North Africa & 35.4 & 6.7 & 41 & 5.6 \\
\hline South-Asia & 82.6 & 8.2 & 100 & 6.5 \\
\hline Sub-Saharan Africa & 21.5 & 5.5 & 26 & 6.5 \\
\hline
\end{tabular}

$\mathrm{e}=$ estimate; $\mathrm{f}=$ forecast

Source: Outlook for Remittance Flows \& Author's Construction

The wealthy or developed nations are the remittance sender while developing or poor countries are remittances receiver as many people migrate from developing countries to developed countries. The top five remittance receiving countries are India, China, Mexico, Philipines, France and Germany while top five remittance sending countries are United States, Saudi Arabia, Switzerland, Russian Federation and Germany (Migration and Remittances Fact Book- 20011).

The role of remittances in improving economic growth remains blurred, despite a large number of studies on the effect of remittances on economic growth. Many studies has confirms a positively association between remittances and economic growth (Ziesemer, 2006; Loxley, Sackey, 2008; Giuliano and Ruiz-Arranz, 2009). But there are many studies that confirms either a negative association or no association between remittances and economic growth (Barajas et al., 2009; Rajan and Subramaniam, 2005). Therefore, there are contradictory findings from current research on the effect of remittances on economic development. So the studies that supports the positive effect of remittances argued that remittance improves the standard of living of left behind family members and enables them to invest in education and healthcare while those studies that supports negative or zero impact of remittance argued that inflation increases due the inflow of remittances which induce recipient to increase leisure and reduce work. So, this confirms that impact of remittance on economic growth has contradictory findings (Chami et al., 2005).

\subsection{Stylized Facts About Remittances in Pakistan}

Inflow of remittances in Pakistan have a rather fluctuating history. During 1960s, the inflow of remittances to Pakistan were so meager or less than one percent (Ali, 2020). The inflow of remittances started increasing in late 1970s when Gulf Cooperation Council (GCC) countries started looking for cheap labour toward Pakistan. Remittances began to grow and peaked at 9.1 percent of the national economy in 1982-1983. After that, during 1987-1988, it started declining and reached just 5.3\%. Recently Government of Pakistan has initiated many remittances 
initiative projects to give facilities to overseas Pakistanis who used official channel for transferring their income to Pakistan. These foreign exchange incentives enable Pakistan to receive $\$ 23.120$ billion in the fiscal year 2019-2020.

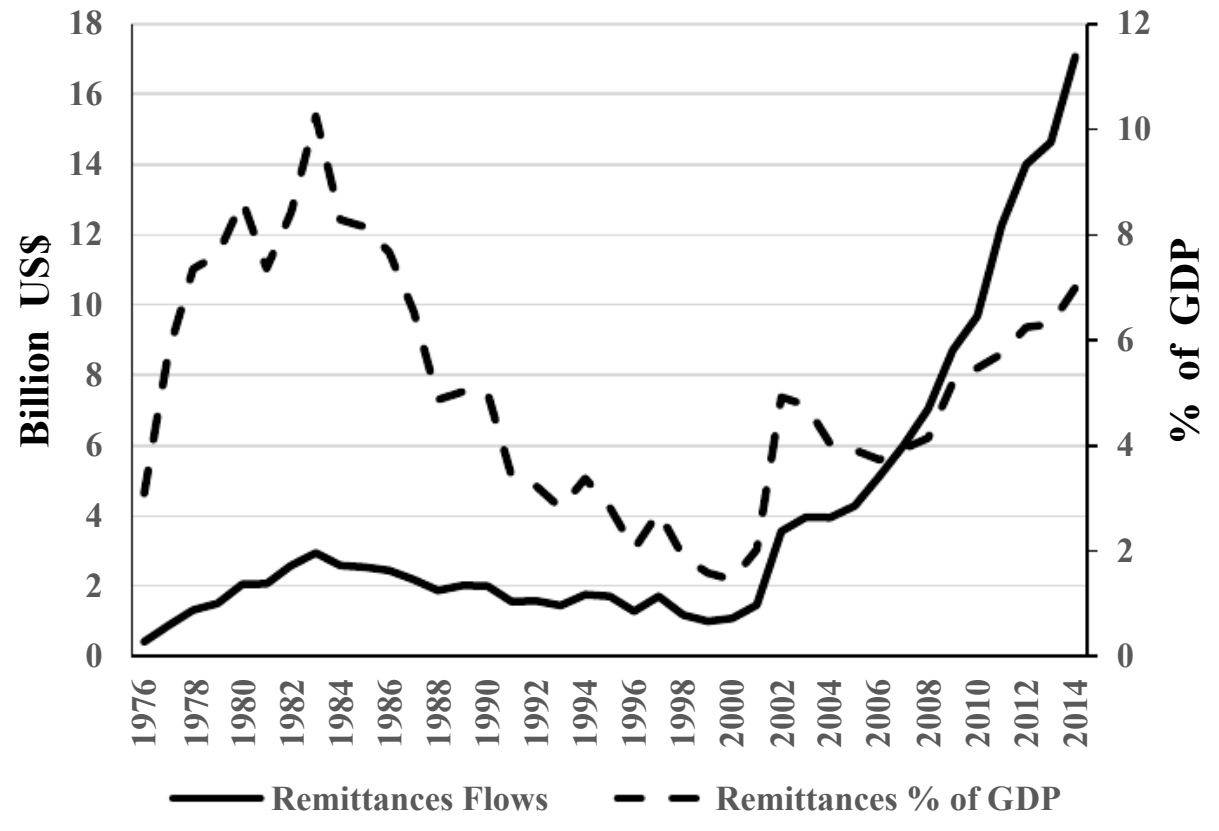

Figure 1 Remittance flows to Pakistan (1976-2014) in US\$ billion and Percent of GDP

Source: World Development Indicator (2016) \& Author's Construction

The growth impact of remittances to Pakistan is analyzed in this paper. Pakistan receives remittances worldwide, but the majority or ninety percent of these international funds comes from twenty three major source countries (Mustafa and Ali, 2018). As Pakistan is the top labour exporting country, so Pakistan receive substantial amount of money in the form of remittances. During the financial year 2018, Pakistani has transferred US\$ 16.96 billion which indicates a prominent role of Pakistan in the remittance countries. Because of these facts, the analysis of remittance determinants is important and significant for policy decision-making and their effect on the welfare of left behind of family members as well as on the macroeconomic situation of Pakistan.

\section{LITERATURE REVIEW}

Economists have given a lot of importance and attention to the economic growth and remittances nexus and there is an immense literature on the Remittance led Growth. Lucas and Stark, (1985) presented the concept of motivations to remit in their path-breaking study and divided motivations into three categories: Pure Altruism, Pure Self-Interest, and Tempered Altruism or Enlightened Self-Interest.

Many studies of academicians and econometricians shed light on the social and welfare effect of remittances (Siddiqui and Kemal, 2006; Ziesemer, 2006; Fajnzylber and Lopez, 2007; Gupta, Pattillo, and Wagh, 2007; Bhaskara Rao and Gazi Hassan, 2009, and Shahbaz, Rehman and Mahdzan, 2013) while numerous studies linked remittances to schooling decisions (Edwards and Ureta, 2003), employment patterns (Amuedo-Dorantes and Pozo, 2006), income inequality (Docquier and Rapoport, 2003), agriculture (Khan S.D., et al., 2019), women empowerment (Kumar, B., 2012), exchange rates (Amuedo-Dorantes and Pozo, 2004)., and total stocks of migrants (Singh et al., 2011). 
Alburo and Abella (1992) use a data of 600 returns migrant in the Philippines and collect a questionnaire-based data. He studies the impact of workers' informal remittances to the Philippines economy and found that the foreign exchange in the form of remittances is used in the trade activity in the country as well as this produces a multiplier effects in the whole economy.

Eftimoski, D. and Josheski, D. (2020) studied the remittance-consumption-growth nexus in emerging Central, Eastern and Southeastern European (CESEE) countries. This study finds a negatively significant and linear association between remittances and economic growth by using two-step system generalized method of moments (GMM) estimator.

Chami, Fullenkamp and Jahjah (2005) discuss the role of remittances as capital flows and compare it with other capital flows like FDI. They set a very simple notion that if remittances act like other capital flows then they must be positively related with the Economic Growth. Their sample included 113 countries and the data period ranges from 1970-1998. The panel aggregate data comes from the World Development Indicators. They reported that inflow of remittance negatively affect the per capita GDP growth. Similarly Barajas et at., (2009) also reported negative association between remittances on Economic growth by taking the data of 84 economies from 1970 to 2004.

Paola Giuliano and Marta Ruiz-Arranz (2009) examine a sample of over developing 100 countries and the data consists from 1975 to 2002. Data has divided into 6 non-overlapping, 5years period but the last period of three years only. They find that remittance and growth have positive relationship especially remittances promotes growth in less financially developed economies. They also find that Remittances can be used as a substitute for financial services in promoting growth and even further when market fail to provide credit, remittances fulfil the needs for credit and insurance.

Feeny, Iamsiraroj and McGillivray (2012) study the effects of remittances on economic growth in the panel of 136 developing countries including 25 Small Island Developing States (SIDS). The data ranges from 1071 to 2010. The whole data are averaged over eight five-year periods, and there are 694 observations, of which 133 are for SIDS. This study confirms a positive impact of remittances on economic growth in Small Island Developing States.

Salahuddin (2013) studies the long run association between remittance and economic growth in four Asian economies, Pakistan, India, Bangladesh and Philippines. The data from 1977 to 2009 confirms the long run positive relationship between migrant's remittances and economic growth within the panel.

\section{DATA AND METHODOLOGY}

The object of this study is to find the short run and long run association between the economic growth and personal remittances inflow in an emerging country like Pakistan. The remittances data has taken from the state bank of Pakistan and in US\$ million. The drawback of the data published is that the number of remittances sent through informal (Hawala or Hundi) channels is most likely to be underestimated. While Arif (2009) reports that half of the remittance to Pakistan comes from Persian Gulf use informal channel. The economic growth (GDP) data is in current US\$ - Billion and has taken from world development indicator (WDI-2020). The descriptive statistics is shown in table 1. 
Table 2 Summary Statistics

\begin{tabular}{lcc}
\hline \multicolumn{1}{c}{ Statistic } & GDP & REM \\
\hline Mean & $1.06 \mathrm{E}+11$ & $5.86 \mathrm{E}+09$ \\
Median & $6.27 \mathrm{E}+10$ & $2.49 \mathrm{E}+09$ \\
Maximum & $3.15 \mathrm{E}+11$ & $2.22 \mathrm{E}+10$ \\
Minimum & $1.32 \mathrm{E}+10$ & $4.12 \mathrm{E}+08$ \\
Std. Dev. & $9.18 \mathrm{E}+10$ & $6.61 \mathrm{E}+09$ \\
Skewness & 0.964568 & 1.378496 \\
Kurtosis & 2.550076 & 3.406881 \\
Jarque-Bera & 7.193988 & 14.23868 \\
Probability & 0.027406 & 0.000809 \\
Sum & $4.66 \mathrm{E}+12$ & $2.58 \mathrm{E}+11$ \\
$\quad$ Sum Sq. & $3.63 \mathrm{E}+23$ & $1.88 \mathrm{E}+21$ \\
Dev. & & \\
$\quad$ Observation & 44 & 44 \\
S & & \\
\hline
\end{tabular}

Source: Author's calculation

\section{EMPIRICAL RESULTS}

The simple autoregressive unit root test improved by Said and Dickey (1984) to fit general $\operatorname{ARMA}(\mathrm{p}, \mathrm{q})$ models with uncertain orders for complex dynamic time series results called the augmented Dickey Fuller (ADF) test. While, to verify the linearity of the data, Phillips and Perron (1988) have established several unit root tests. Any serial correlation in test regression is ignored by the PP tests. To check the linearity of the two series, Augmented Dickey-Fuller (ADF) and Phillips-Perron (PP) unit root test are used and the results of both tests has shown in Table 2.

Table 3 Unit Root Test

\begin{tabular}{|c|c|c|c|c|c|c|c|c|}
\hline \multirow[t]{3}{*}{ Variables } & \multicolumn{4}{|c|}{ Augmented Dickey Fuller test (ADF) } & \multicolumn{4}{|c|}{ Phillip-Perron Test (PP) } \\
\hline & \multicolumn{2}{|c|}{$\mathbf{I}(\mathbf{0})$} & \multicolumn{2}{|c|}{$\mathbf{I}(\mathbf{1})$} & \multicolumn{2}{|c|}{$\mathbf{I}(\mathbf{0})$} & \multicolumn{2}{|c|}{ I(1) } \\
\hline & $\mathbf{C}$ & $\mathbf{C} \& \mathbf{T}$ & $\mathbf{C}$ & $\mathbf{C} \& \mathbf{T}$ & $\mathbf{C}$ & $\mathbf{C} \& \mathbf{T}$ & $\mathbf{C}$ & $\mathbf{C} \& \mathbf{T}$ \\
\hline Lgdp & -1.516395 & -2.438806 & $-5.533735^{*}$ & $-5.602264 *$ & -1.516395 & -2.524818 & $-5.445140^{*}$ & $-5.596835^{*}$ \\
\hline Lrem & -1.032826 & -1.437846 & $-5.448981^{*}$ & $-5.385433^{*}$ & -1.180119 & -1.842606 & $-5.449766^{*}$ & $-5.385433^{*}$ \\
\hline
\end{tabular}

Note: * indicates $1 \%$ level of significance.

Source: Author's Construction

The unit root test indicates that both variables are stationary at level 1 or I(1), so we apply co-integration analysis. Before co-integration, we find the lag length and the result is presented in table.

Initially, we determine the lag intervals for endogenous of our VAR model. The lag length criteria indicates maximum four lag. The AIC value is small while the value of log probability function is very high for the model which means that the model's explanatory potential is quite strong. 
Table 4 Lag length Criteria

\begin{tabular}{ccccccc}
\hline \hline Lag & LogL & LR & FPE & AIC & SC & HQ \\
\hline \hline & & & & & & \\
0 & -1876.408 & NA & $2.96 \mathrm{e}+40$ & 98.86355 & 98.94974 & 98.89422 \\
1 & -1754.549 & 224.4761 & $5.99 \mathrm{e}+37$ & 92.66048 & $92.91904^{*}$ & 92.75247 \\
2 & -1752.877 & 2.903351 & $6.78 \mathrm{e}+37$ & 92.78302 & 93.21397 & 92.93635 \\
3 & -1745.865 & 11.44084 & $5.82 \mathrm{e}+37$ & 92.62449 & 93.22781 & 92.83915 \\
4 & -1737.165 & $13.27998^{*}$ & $4.59 \mathrm{e}+37 *$ & $92.37709^{*}$ & 93.15278 & $92.65307 *$ \\
5 & -1735.471 & 2.407421 & $5.27 \mathrm{e}+37$ & 92.49845 & 93.44652 & 92.83577 \\
6 & -1734.081 & 1.828007 & $6.18 \mathrm{e}+37$ & 92.63585 & 93.75631 & 93.03450
\end{tabular}

Note: * indicate maximum lag length.

Source: Author's Construction

After calculating the lag order, the VAR model is established. Figure 1 then displays the test stationarities of the VAR model and the mod of the AR characteristic root reciprocal which further, that the lag order of 4 is acceptable.

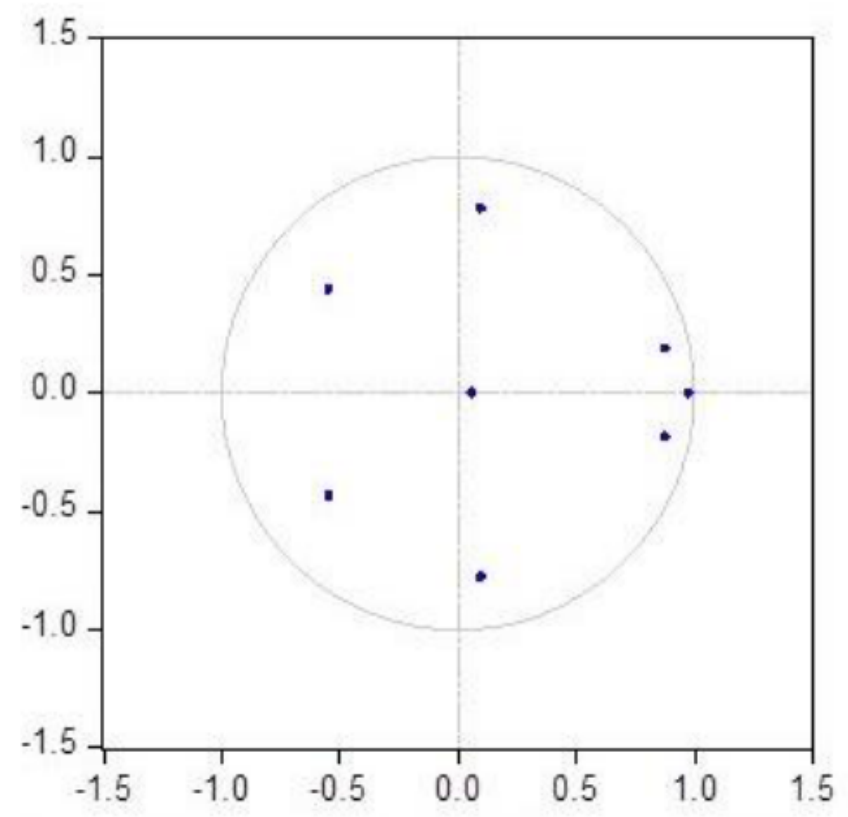

Figure 2 Inverse Roots of AR Characteristic Polynomial

If all roots have a modulus of less than one and lie inside the unit region, the approximate VAR is stable or stationary (Lütkepohl, 1991). Figure 1 confirms that the reciprocal mod is in the circle for each root function, confirming that the lag order 4 is acceptable and that the VAR model is stable.

Johansen co-integration test on economic growth (GDP) and inflow of foreign remittances is presented in Table 4 confirming that the results of both, trace and maximum eigenvalue statistic are acceptable. The null hypothesis of both statistic are acceptable under the $5 \%$ level. So, one positive relationships between the variables confirmed through the results of Johansen co-integration. The results of Johansen co-integration in table 4 farther confirms the stability and long-term equilibrium relationships between the variables. 
Table 5 Johansen Co-integration

\begin{tabular}{llllll}
\hline $\begin{array}{l}\text { Hypothesized } \\
\text { No. of CE(s) }\end{array}$ & Eigenvalues & $\begin{array}{l}\text { Trace } \\
\text { Statistic }\end{array}$ & $\begin{array}{l}\text { Trace } \\
\text { Probabilities }\end{array}$ & $\begin{array}{l}\text { Max- } \\
\text { Eigen } \\
\text { Statistic }\end{array}$ & $\begin{array}{l}\text { Max-Eigen } \\
\text { Probabilities }\end{array}$ \\
\hline None* & 0.476273 & $\begin{array}{l}36.95149 \\
(29.79707)\end{array}$ & 0.0063 & $\begin{array}{l}22.63745 \\
(21.13162)\end{array}$ & 0.0305 \\
At most 1 & 0.279018 & $\begin{array}{l}14.31404 \\
(15.49471)\end{array}$ & 0.0747 & $\begin{array}{l}11.44993 \\
(14.26460)\end{array}$ & 0.1331 \\
At Most 2 & 0.078573 & $\begin{array}{l}2.864104 \\
\text { (3.841466) }\end{array}$ & 0.0906 & $\begin{array}{l}2.864104 \\
(3.841466)\end{array}$ & 0.0906 \\
\hline
\end{tabular}

Note: * Rejection of hypothesis at 0.05 level

**MacKinnon-Haug-Michelis (1999) p-values

Critical values in parentheses

Source: Author's calculation

The result of Johansen Co-integration shown in table 4. The Trace statistic and Maxeigenvalue statistic indicates one co-integrating equation at the 0.05 level. This result confirms linear relationship or long run relationship among variables. As all variables are stationary level first difference and co-integration exist among variables so we apply VECM.

For integrated series, time series models are typically based on applying VAR to first differences. Differentiation, however, removes useful knowledge about the integrated series relationship - this is where the Vector Error Correction Model (VECM) is applicable. (Lütkepohl, H., 1991).

Co-integration results reveal that long-run equilibrium relationships present between GDP and remittances. Now for the short-run relationship between the variables, we apply Vector Error Correction Model (VECM). We take VECM lag order 3 because our VAR lag order is 4 and VECM result is presented as equation 1 and 2.

The co-integrating equation and long run model is

$$
\begin{aligned}
& E C T_{t_{-1}}=1.0000 \operatorname{lgdp}_{t_{-1}}-0.7526 \text { lrem }_{t-1}-8.4910 \quad-------\rightarrow 1 \\
& \Delta l g d p_{t}=-0.0155 E C T_{t-1}-0.0454 \operatorname{lgdp}_{t-1}+0.0609 \text { lrem }_{t-1}+0.0601 \\
& \longrightarrow----\longrightarrow 2
\end{aligned}
$$

As in causality test, both variables are dependent and independent, in Granger Causality only two variables will be considers at a time.

Table 6 Pairwise Granger Causality Test

Pairwise Granger Causality Tests

\begin{tabular}{lccc}
\hline \hline Null Hypothesis: & Obs & F-Statistic & Prob. \\
\hline \hline REM does not Granger Cause GDP & 43 & 0.80322 & 0.3755 \\
GDP does not Granger Cause REM & & 9.62723 & 0.0035 \\
\hline \hline
\end{tabular}

Source: Author's Construction

The Granger Causality result confirms that there is uni-directional causality run from GDP to Remittances

To check the parameters stability, this study apply CUSUM and CUSUMQ tests (Brown et al., 1975). Cumulative sum test helps to show if coefficients of the regression are changing systematically while Cumulative sum of square test is helpful to showing if the coefficients of 
the regression changing suddenly (Bhatti, Al-Shanfari et al., 2006). The result of both the tests shown in diagram 1.
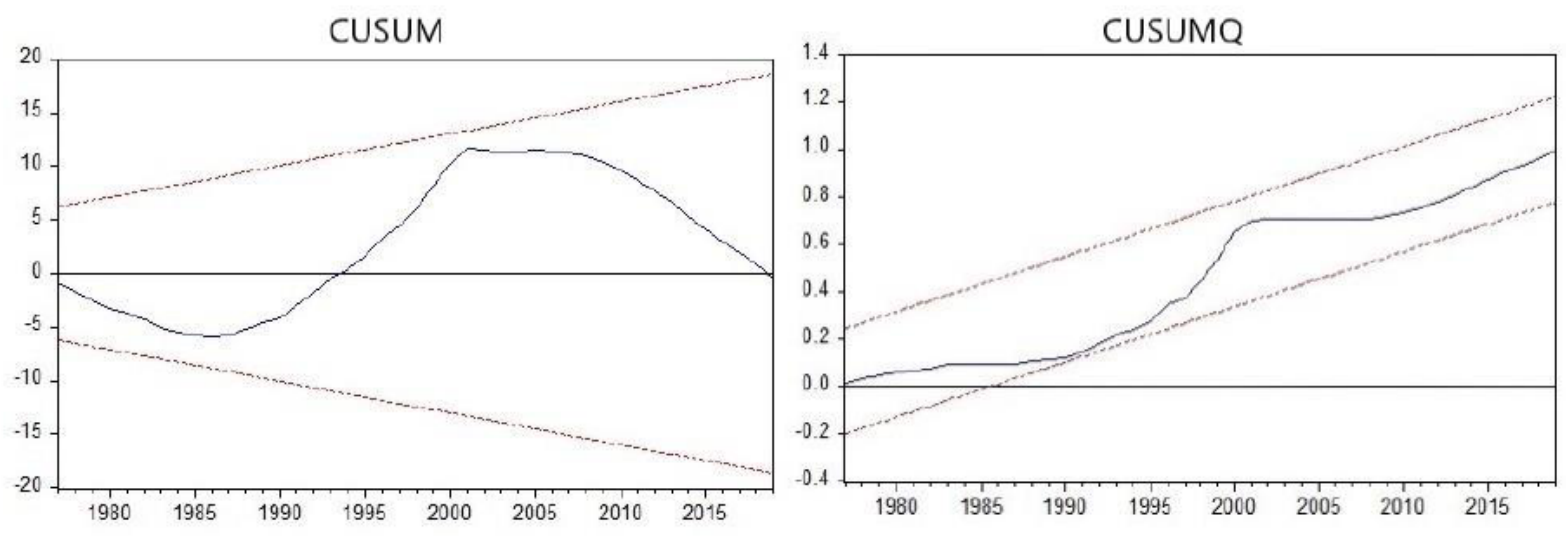

Figure 3 Cusum and CusumQ test

Source: Author's Construction

The cumulative sum and cumulative sum of squares, in both, the CUSUM and CUSUMQ tests lie within the $5 \%$ critical lines which confirms the stability of parameters.

\section{CONCLUSION \& POLICY IMPLICATION}

This study investigates the short and long run association between remittances and economic growth using the time series data from 1976 to 2019 by applying different time series estimation techniques like Johansen co-integration, VAR and VECM. The remittance data comes from State Bank of Pakistan and in US\$ million while Economic Growth or GDP data comes from world economic indicator, World Bank and in current US\$. The results confirms that both shortrun and long-run association exist between remittances and economic growth in Pakistan. Thus, results show that, the remittance flows to Pakistan have a positive impact on Individual Pakistani as well as on macroeconomic scenario of Pakistan. The results parameters stability tests, CUSUM and CUSUMQ confirms the stability of parameters. Government should adopt such policies that encourage overseas Pakistanis to send remittances through official channel.

\section{REFERENCES}

[1] Alburo, F. A., \& Abella, D. I. (1992). The Impact of Informal Remittances of Overseas Contract Workers' Earnings on the Philippine Economy. Asian Regional Program on International Labour Migration Working Paper. Bangkok: ILO.

[2] Alejandra Cox Edwards, Manuelita Ureta. (2003). International migration, remittances, and schooling: evidence from El Salvador. Journal of Development Economics. 72(2):429-461. https://doi.org/10.1016/S0304-3878(03)00115-9.

[3] Ali, S. R. (2020). The pattern, sources, and growth of remittances to Pakistan: The kinked exponential approach. Journal of Research in Emerging Markets, 2(1), 1-6. https://doi.org/10.30585/jrems.v2i1.383

[4] Amuedo-Dorantes, C. and S. Pozo. (2006). Migration, remittances and male and female employment patterns. American Economic Review. 96(2):222 - 226.

[5] Arif, Ghulam M. (2009). Economic and Social Impacts of Remittances on Households: The Case of Pakistani Migrants Working in Saudi Arabia. Published by Pakistan Institute of Development Economics (PIDE) Islamabad for International Organization for Migration. 
[6] Barajas, A., Chami, R., Connel, F., Gapen, M. and Montiel, P. (2009). Do Workers' Remittances Promote Economic Growth? IMF Working Paper, WP/09/153, Washington.

[7] Bhaskara Rao and Gazi Hassan. (2009). A panel data analysis of the growth effects of remittances. MPRA Paper No. 18021. http://mpra.ub.uni-muenchen.de/18021/

[8] Brown, R., J. Durbin and J. Evans (1975). Techniques for testing the constancy of regression relations over time. Journal of the Royal Statistical Society. 37(2):149-163. https://doi.org/10.1111/j.2517-6161.1975.tb01532.x

[9] Catalina Amuedo-Dorantes, Susan Pozo. (2004). Workers' Remittances and the Real Exchange Rate: A Paradox of Gifts. World Development. 32(8):1407-1417. https://doi.org/10.1016/j.worlddev.2004.02.004.

[10] Chami, Ralph, Connel Fullenkamp, and Samir Jajah. (2005). Are Immigrant Remittance Flows a Source of Capital for Development?. IMF Working Paper 03/189 (Washington: International Monetary Fund).

[11] Docquier, F. and Rapoport, H. (2003). Remittances and Inequality: A Dynamic Migration Model. IZA Discussion Paper 808.

[12] Economic data. State Bank of Pakistan. https://www.sbp.org.pk/ecodata/index2.asp

[13] Eftimoski, D. and Josheski, D. (2020). Reopening the debate on the relationship among remittances, household consumption stability and economic growth in emerging markets. International Journal of Emerging Markets. Vol. ahead-of-print No. ahead-ofprint. https://doi.org/10.1108/IJOEM-02-2020-0160

[14] Engle, R., \& Granger, C. (1987). Co-Integration and Error Correction: Representation, Estimation, and Testing. Econometrica, 55(2):251-276. https://doi.org/10.2307/1913236

[15] Fajnzylber, P., and J. H. Lopez. (2007). Close to Home: The Development Impact of Remittances in Latin America. mimeo (Washington: World Bank).

[16] Khan, S.D., S.R. Ali and S.W. Khattak. (2019). Exchange rate volatility and cotton producer's behaviour: Evidence from Pakistan. Sarhad Journal of Agriculture. 35(4):1259-1265. http://dx.doi.org/10.17582/journal.sja/2019/35.4.1259.1265

[17] Kumar, B., Ali, S. R., \& Kibria, M. G. (2021). International Remittances, Household Welfare, and Women Empowerment: Evidence From Bangladesh. In Dixit, S., \& Moid, S. (Ed.), Women Empowerment and Well-Being for Inclusive Economic Growth (pp. 174-190). http://doi:10.4018/978-1-7998-3737-4.ch012

[18] Loxley, J. and Sackey, H.A. (2008). Aid Effectiveness in Africa. African Development Review. 20:163-199. https://doi.org/10.1111/j.1467-8268.2008.00181.x

[19] Lucas, Robert, and Oded Stark. (1985). Motivations to Remit: Evidence from Botswana. Journal of Political Economy. Vol. 93(5):901-18. https://www.journals.uchicago.edu/doi/10.1086/261341

[20] Lütkepohl, Helmut (1991).Introduction to Multiple Time Series Analysis. Springer-Verlag Berlin Heidelberg. DOI: 10.1007/978-3-662-02691-5 
[21] Mustafa, K., \& Ali, S. R. (2018). The Macroeconomic Determinants of Remittances in Pakistan. International Journal of Business Management and Finance Research, 1(1):1-8. https://academiainsight.com/ijbmfr/article/view/25

[22] Paola Giuliano, Marta Ruiz-Arranz. (2009). Remittances, financial development, and growth. Journal of Development Economics. 90(1):144-152. https://doi.org/10.1016/j.jdeveco.2008.10.005.

[23] Peter C. B. Phillips, Pierre Perron. (1988). Testing for a unit root in time series regression. Biometrika. 75(2):335-346. https://doi.org/10.1093/biomet/75.2.335

[24] Rajan, R. G. and Subramaniam, A. (2005). What Undermines Aid's Impact on Growth?” NBER Working Paper, 11657.

[25] Ratha, D., S. Mohapatra, and A. Silwal. (2011). Outlook for Remittance Flows 2011-2013. Migration and Development Brief, No. 16, World Bank. Migration and Remittances Fact book 2011. The World Bank.

[26] Said E. Said, David A. Dickey. (1984). Testing for unit roots in autoregressive-moving average models of unknown order. Biometrika. 71(3):599-607. https://doi.org/10.1093/biomet/71.3.599

[27] Salahuddin, Mohammad. (2013). Empirical link between growth and remittance: evidence from panel data. Journal of Applied Business and Economics. 14(5). https://eprints.usq.edu.au/23544/

[28] Sanjeev Gupta, Catherine A. Pattillo, Smita Wagh. (2009). Effect of Remittances on Poverty and Financial Development in Sub-Saharan Africa. World Development. 37(1):104-115. https://doi.org/10.1016/j.worlddev.2008.05.007.

[29] Siddiqui, R., and A. R. Kemal. (2006). Remittances, Trade Liberalisation, and Poverty in Pakistan: The Role of Excluded Variables in Poverty Change Analysis. The Pakistan Development Review. 45(3):383-415.

[30] Esiefarienrhe Michael Bukohwo, Djibo Idrissa, Irorakpor H. T., "Computer-BAsed VAT Collection System For Federal Inland Revenue Service- Gombe Integrated Office"., Global Journal of Engineering Science \& Researches (GJESR), 2014, 1(6), pp 23-28

[31] Simon Feeny, Sasi Iamsiraroj \& Mark McGillivray. (2014). Remittances and Economic Growth: Larger Impacts in Smaller Countries?. The Journal of Development Studies. 50(8):1055-1066. DOI: 10.1080/00220388.2014.895815

[32] Singh, R., Haacker, M., Lee, K.-W. and Goff, M.L. (2011). Determinants and macroeconomic impact of remittances in Sub-Saharan Africa. Journal of African Economies. 20(2):312-340.

[33] Shahbaz, Rehman and Mahdzan. (2013). Linkages between Income Inequality, International Remittances and Economic Growth in Pakistan. MPRA Paper No. 45577. http://mpra.ub.unimuenchen.de/45577/

[34] World development indicators. Washington, D.C.: The World Bank.

[35] Ziesemer Thomas H.W., (2009). Worker Remittances and Growth: The Physical and Human Capital Channels. Journal of Economics and Statistics (Jahrbuecher fuer Nationaloekonomie und Statistik), De Gruyter. 229(6):743-773.

Funding Details: There is no funding for this paper

Disclosure Statement: There is no potential conflict of interest among authors. 